\title{
The Contemporaneity of 'Counter-Enlightenment'. From the French Revolution to German Post-War Sociology
}

Sonja Asal

HCM 7: 940-970

DOI: $10.18352 / \mathrm{hcm} .590$

\begin{abstract}
While resistance to Enlightenment thought occurring in the eighteenth century is often framed by the concept of 'Counter-Enlightenment', the term itself was not introduced before the twentieth century. The article first reconstructs the anti-Enlightenment polemic before and after the French Revolution to highlight that while the notion of CounterEnlightenment is appropriate for the identification of hitherto unexplored strands of thought, in view of a broader and more differentiated approach to the intellectual history of the eighteenth and early nineteenth centuries, it does not allow for a substantial definition. Subsequently, the article examines the history of the concept in French, English and German linguistic contexts, the German sociology of the interwar period and discussions about the legacy of the Enlightenment after World War II, to retrace how the different iterations have to be understood as a key for the self-reflection of modern societies throughout the twentieth century.
\end{abstract}

Keywords: anti-modernity, conceptual history, Counter-Enlightenment, counter-revolution, early conservatism, history of sociology

\section{Introduction}

'Who wants to extinguish the Enlightenment?', captioned an article in the French newspaper Le Monde in November 20I8. ${ }^{\mathrm{I}}$ The authors 
describe how the public sphere is increasingly turning away from ideals of progress, rationality and universality in favour of religion and nationalism, of an ever more radical New Right that openly attacks the legacy of the Enlightenment and refers to the thinkers and motifs of the Counter-Enlightenment. To invoke the Counter-Enlightenment in a daily as explicitly as these authors did seems surprising, yet there is ample evidence of the currency of the word in other languages and media. The Counter-Enlightenment is topical. There appears to be a common understanding of what the expression refers to: basically, it denotes anti-democratic, authoritarian and reactionary positions, and the defence of anti-universalist, anti-egalitarian and anti-emancipatory convictions. The term still resonates with the erstwhile clash between the proponents of the Enlightenment and their opponents, those who championed throne and altar, and represented clergy and monarchy. How can we understand the fact that contemporary political conflicts are still formulated in terms of the battle between Enlightenment and Counter-Enlightenment? How is the concept used, and what can its history tell us about our own time?

As many historians have remarked, while 'Counter-Enlightenment' and its German and French equivalents depict a century-old phenomenon, the designations themselves are quite recent. Consequently, there have been and still are debates among specialists of the eighteenth century whether anything like the 'Counter-Enlightenment' occurred at all and whether the term denotes a limitable and substantial entity. Some have called it an 'invention', ${ }^{2}$ others have claimed that it did not exist at all or have at least advised against the scholarly use of the term. ${ }^{3}$ There have also been heated debates about the question whether individual authors are justly or wrongly counted as belonging to it. ${ }^{4}$ In this special issue Darrin McMahon discusses the uses and abuses of the term, and I subscribe to his conclusion that "no amount of quibbling about labels can deny the existence of movements self-consciously organized around opposition to the values and principles they associated with the "Enlightenment". ${ }^{5}$ McMahon points to the fact that even though the existence of the Counter-Enlightenment has been seriously questioned, the literature about it has boomed in recent years. If one takes as an indication the fact that only a few years ago a dictionary on the French strand of Anti-Lumières and Antiphilosophes was published, then the subject definitely has made its way to the core of historical investigation. ${ }^{6}$ But still, as McMahon underscores, this is only the 
beginning of the research that has to be done on the subject, and this research begins with the very evaluation of the scope of the term.

As a point of departure, I will take the obvious non-simultaneity between the historical phenomena under scrutiny on the one hand, and the emergence of the terms used to describe them on the other. My initial hypothesis, which will be further developed below, is that the reason the field is so highly charged is because the terms used to designate the concept of a Counter-Enlightenment were established only in highly charged ideological contexts in the twentieth century.

As Counter-Enlightenment movements developed in different European countries, different linguistic contexts have to be considered. The terms 'Counter-Enlightenment', Anti-Lumières and Gegenaufklärung have divergent associations in their respective languages. This is not least due to the fact that the phenomenon referred to in the suffix, namely the Enlightenment, took a different course in the cultural contexts of England, Scotland, the United States, France and the German-speaking lands. In consequence, the concept of Enlightenment itself has different temporal indices in the various linguistic spheres. Whereas le siècle des Lumières and Aufklärung are concepts of the eighteenth century, the Anglophone 'Enlightenment' became common only in the late nineteenth century. The first publication to use the word 'Enlightenment' in its title was John Greer Hibbon's The Philosophy of the Enlightenment (I9I0). ${ }^{7}$

This non-simultaneity between phenomenon and denomination is overlaid by a profound ambiguity, which in many ways reflects the scope of the term Enlightenment. 'Enlightenment' is used to designate a historical epoch as well as the "master narrative" of modernity', as Dan Edelstein puts it, ${ }^{8}$ with its normative value up to the present day. To this corresponds the use of 'Counter-Enlightenment' as denoting all anti-rationalist, anti-intellectualist strands of thought that reject universal ideas. In this sense, the concept was brought to the fore by Isaiah Berlin, who has strongly influenced its use to this day. Following him, authors like Zeev Sternhell appreciate the term as an analytical instrument, deeming it indispensable for the evaluation of the political catastrophes of the twentieth century. ${ }^{9}$ Both authors consider the historian Giambattista Vico as predecessor of anti-Enlightenment thought. In their view, it was continued by Edmund Burke and Johann Gottfried Herder, and culminated in the nationalism and fascism of the twentieth century. ${ }^{10}$

In what follows I will concentrate on the use of the word. The method of historical semantics is key to gaining clarity and obtaining a more 
structural perspective. First I will describe and discuss the CounterEnlightenment as a historical phenomenon, both during the eighteenth century and after the French Revolution. Secondly, I will trace its use by the German sociologists Franz Oppenheimer and Karl Mannheim in the I920s, marking the step from counter-revolutionary thought to the beginnings of the historiography of conservatism. Finally, I will discuss the use of the term as a common feature of opposition to modern society and politics. This ties in with the emergence of the term 'Counter-Enlightenment' in the twentieth century and its French and German equivalents.

\section{Contemporary Reactions to the Enlightenment Before and After the French Revolution}

During the past decades, significant research has been undertaken on the eighteenth and nineteenth-century phenomena that would later be identified as 'Counter-Enlightenment'. ${ }^{\text {II }}$ In the French context, Jean Deprun introduced the term Anti-Lumières as a common denominator for the resistance against the Enlightenment as part of his contribution to a history of philosophy published in I $973 .{ }^{\mathrm{I}} \mathrm{As}$ far as I can see, Deprun was the first to subsume orthodox Catholic as well as spiritualist and illuminist authors under this banner, regarding them as forerunners of Romanticism. ${ }^{\mathrm{I} 3}$ In more recent years, the 'other side' ${ }^{\mathrm{I} 4}$ of the French Enlightenment has been most closely investigated by Didier Masseau and Darrin McMahon. ${ }^{15}$ Both Masseau and McMahon characterize the protagonists involved with the prefix 'anti' or 'counter', as opponents of the dominant intellectual movement of the time. The expression anti-philosophie was already well-established in eighteenth-century France for a more or less systematic set of refutations against philosophic reasoning. ${ }^{16}$ The observation that word formations with 'anti' frequently appeared in combinations like Anti-Dictionnaire philosophique or Anti-Émile suggests that the common denominator of this faction was opposition to the newly emerging philosophy; in the understanding of the time this encompassed philosophical thinking in the strict sense of the word as well as literature and science pursued from a critical stance. In this respect, the publication of the Encyclopédie can be seen as an incubator for the perception of the philosophes as a group, 
although the collaborators on that project did not consider themselves as united by some common ideological goal. ${ }^{17}$ It was rather their opponents who regarded them as such. Even though one could argue that the Enlightenment faction was created and bound together by its opponents, this does not entail that a movement actually existed which called itself, or was called by others, the 'Counter-Enlightenment'.

The largest group of Enlightenment critics in France prior to the Revolution consisted of institutional representatives of Catholic orthodoxy. Albert Monod's De Pascal à Chateaubriand is the oldest, and still the most comprehensive, individual study on the subject, yet it does not focus on the Counter-Enlightenment, nor does it even use the word. Instead, it discusses the apologetic Catholic literature of the eighteenth century. The title of Robert R. Palmer's seminal study is probably the best way to designate groups according to their attitude towards religious belief in eighteenth-century France, indicating the century's central divide as an opposition between 'Catholics' and 'unbelievers'. ${ }^{18}$

One of the most crucial aspects of the research that has been conducted on these groups, however, is the transformation in the field of eighteenth-century studies which can be traced back to a methodological shift in intellectual history, namely from ideas to cultural practices. As Didier Masseau states in the introduction to his Dictionnaire: 'Étudier les anti-Lumières, c'est user d'un nouvel angle d'attaque pour comprendre l'ensemble des productions culturelles du XVIIIe siècle et porter un nouveau regard sur les Lumières elles-mêmes.' ${ }^{19}$ In this regard, not only the ideas of the opposing groups are taken into account, but also their actions within a particular cultural context, which also includes their use of media like pamphlets or journals as well as literary forms like theatre plays or epistolary novels. ${ }^{20}$ Due to the radical character of the French Enlightenment, debates were most intensely fuelled in France: initially in the I750s, right after the publication of the first volumes of the Encyclopédie, and then again after the publication of d'Holbach's Système de la nature. ${ }^{21}$ In German-speaking lands, attacks against the Enlightenment also intensified in the last third of the eighteenth century when the so-called Volksaufklärung ("popular Enlightenment') took a practical and thus more political turn. ${ }^{22}$

If controversy helped shape the Enlightenment, this is all the more true for the time after the French Revolution. Opposition against newly emerging ideas, against the rational foundation of morality and society, 
or the critique of religion and its institutions, was around for as long as the Enlightenment itself, but during the revolution these ideas had become reality. Thus, the revolutionary overthrow was considered the result of free thinking, generally labelled as philosophie. Under these circumstances, the term was given a political twist. Even before the revolution, especially during the I780s, authors loyal to state and church warned against the negative consequences of the Enlightenment both for the constitution and the social order, and they already used the term 'revolution' to denote these developments. ${ }^{23}$ Hence, the postrevolutionary Counter-Enlightenment could follow its predecessors seamlessly, albeit any connection between the apologetic literature of pre-revolutionary and the polemics of post-revolutionary times was rendered invisible by the intervening event of the revolution, often regarded as a point zero. From an early moment on, this movement was labelled as 'Counter-Revolution' by historiographers. As much as works like those by Edmund Burke or Joseph de Maistre and LouisGabriel-Ambroise de Bonald focused on the reaction against the historical events, it was first and foremost their relationship to the revolution itself and not their reaction against Enlightenment ideas that defined their writings. Enlightenment philosophy was only relevant within this context insofar as the authors under scrutiny regarded pre-revolutionary philosophy to be the trigger of later revolutionary events.

The anti-Enlightenment polemic grew into a unifying force once the revolution was over and amalgamated motifs of eighteenth-century philosophy as if in a crucible. Through the interpretation of the revolutionary event, Enlightenment thought quickly became history. The revolution represented a verifiable reality now, and from the perspective of subsequent political events, Enlightenment itself was seen as a mere prelude. Whether it would have produced such a massive and long-lasting interest without subsequent political events is a matter of pure speculation. Yet, intensified reflection on subjects like the telos and meaning of history, political order and the place of the individual within society was undoubtably triggered by the crucial experience of the French Revolution.

The political events of the revolution also proved to be of great significance for the creation of what can be considered an international network of Counter-Enlightenment protagonists. After I789, members of the French aristocracy, various political groups and the church 
left the country in consecutive waves mainly to head for England or the territories east of the Rhine. In these chosen exiles, journals were founded and books printed, often in a vivid exchange with local groups. In London alone, thirteen émigré journals were published between I792 and I8I4, as Simon Burrows points out. With a presence of about ten thousand French emigrants in Great Britain, London soon became the largest publishing epicentre outside of France. ${ }^{24}$ Journals and books took over complementary roles. While 'the books by Barruel, Burke, Gentz, de Maistre, de Bonald, d'Ivernois, Calonne and, indeed, Mallet du Pan and Montlosier offered broad interpretations, the émigré press offered nuance, reinterpretation in the light of events, repetition and reinforcement' ${ }^{25}$ Typically in a banal manner and with little variation, the Enlightenment is usually addressed in articles about the causes of the Revolution of 1789-92. It is the philosophes who are repeatedly accused of having undermined morality, religion and hence public authority, as Jean-Gabriel Peltier, one of London's most influential émigré journalists, argues exemplarily in his Dernier Tableau de Paris. ${ }^{26}$ In the same vein, Jacques Mallet du Pan, editor of the exile journal Mercure britannique, wrote the extensive article 'Du degré d'influence qu'a eue la Philosophie Françoise sur la Révolution' ${ }^{27}$ in which he regards philosophy as the trigger of a 'révolution de l'esprit'. However, he does not blame the likes of Voltaire or Rousseau, but rather their 'blind' disciples, 'petits raisonneurs sans génie \& sans principes' ${ }^{28}$ Compared to other examples, Mallet du Pan's analysis can be called nuanced inasmuch as he points to the inherent discord of the philosopher's faction. Furthermore, he does not consider the philosophers' influence to have had an intellectual impact only, but argues that 'moeurs' and convictions have also been reshaped, not by abstract 'raisonnement' alone, but by novels, pamphlets and a certain tone they informed the public discourse with. ${ }^{29}$

In this regard, Mallet du Pan's attempt differs quite significantly from the more powerful and polemical tendencies of the wide-ranging conspiracy theories that circulated on an international scale by this point. Conspiracy theories had already come up before the revolution. As early as the I780s they started to emerge mainly in the German-speaking lands, way before they could be identified as a reaction to the quickly historicized French Revolution. ${ }^{30}$ The best-known post-revolutionary work that focused on the revolution as a result of a conspiracy was 
Augustin Barruel's Mémoires pour servir à l'histoire du jacobinisme, published in 1797 and 1798 in London. The overall four volumes became an immediate success and were translated from French to other major European languages shortly after their initial release.

The publication history of Barruel's multi-volume work illustrates well to what degree cooperation took place on a European scale. Barruel's publication was greeted with the enthusiasm of two Germans, the anti-revolutionary publicists Johann August Starck and Ludwig Adolf Christian von Grolmann. They corresponded with Barruel, who at the time was supported by Edmund Burke in his English exile. To fuel Barruel's speculations, Starck and Grolmann sent him a series of antiEnlightenment and anti-Masonic pamphlets after the release of the first volume of Mémoires, which Barruel then used for the second volume. ${ }^{31}$

A few years later Starck himself anonymously published The Triumph of Philosophy in the Eighteenth Century. ${ }^{32}$ Across hundreds of pages he meticulously outlines the ways in which philosophy - or, as he mostly calls it contemptuously, 'philosophism' - had brought about the French Revolution by its impact on religious, political and moral issues. In the introduction, he states:

\begin{abstract}
Philosophy has, in our times, carried away so great a triumph, so unexpected, and not only for the scholars, but also for the thrones and altars, and so important a triumph for all classes of bourgeois society, that it deserves more than any other to have its story told to its offspring, that they be able to understand precisely the causes thereof, the means employed by the philosophers to attain it, and to know precisely its nature, its effects, and its consequences. ${ }^{33}$
\end{abstract}

In his footnotes, Starck repeatedly refers to Barruel being a witness for his claim. As this example shows, the resistance against the consequences of the revolution fell, as it were, into the hands of a FrancoGerman counter-revolutionary International.

As similar as the rejection of Enlightenment philosophy may have turned out in both countries, there was, however, a significant difference between France and the German-speaking lands, since the German reaction against the Enlightenment took on a Francophobe tone early on. The cultural hegemony of France had been an important factor in spreading Enlightenment philosophy across Europe during 
the eighteenth century. After the revolution, the German iteration of the anti-Enlightenment movement grew ambivalent and referred to Enlightenment thought as something that had been brought forth by French culture itself. According to John Pocock, already Herder's cultural philosophy can be described as 'to an important extent anticolonial ideology', founded upon 'the rebellion of German imagination against French cultural hegemony' ${ }^{34}$ In the second half of the nineteenth century, when German cultural self-perception was often shaped in opposition to France, this attitude eventually became compatible with the then rising national chauvinistic positions. ${ }^{35}$ In his work on Voltaire published in I 885, for example, the literary historian Richard Mahrenholtz (I849-I909) opposes Voltaire's French 'frivolity' to Frederick II's 'hale and healthy German disposition'. ${ }^{36}$

In a nutshell, counterrevolutionary positions can be described as part of a greater Counter-Enlightenment movement, but only insofar and inasmuch as they take into consideration the Enlightenment's role as a trailblazer of the revolution. In France, this is the case for Bonald and Maistre, to name but the most prominent proponents, for whom Rousseau's social contract theory represents the fatal signal for the revolutionary destruction of society. Against the philosopher's sovereign individual, both defend a social order dictated by divine creation which was shaped in the course of history. Social, governmental and cultural institutions are therefore based on a centuries-old tradition that in turn guarantees their stability. By means of these motifs, a form of thought begins to emerge which would later be described as 'conservative'. In Germany, where the publicists Friedrich von Gentz and August Wilhelm Rehberg ${ }^{37}$ were influential representatives of an emerging conservative movement, the situation was similar. To this day, Gentz is well-known for not only having translated Edmund Burke's Reflections into German, but also for controlling their reception through a detailed commentary. ${ }^{38}$ For Gentz as for Rehberg, their own present, understood as part of a historical process, is at the centre of reflection. It is exactly this invocation of history, understood as the stabilization of tradition, which becomes a central conservative line of argument. ${ }^{39}$

All these conservative tendencies emerge during the nineteenth century, while they in themselves correspond to eighteenth-century motifs: the emphasis on tradition against the valorisation of the new, 
the romantic accentuation of feeling against the rationalism of the Enlightenment, the reference to (divine) authority against the claim of emancipatory autonomy, increased religious conformism, the strengthening of ultramontane tendencies in the Catholic Church against the question of the role of the Church in society and the state. To retrospectively dub this collection of themes Counter-Enlightenment, however, would be questionable in light of the different situations associated with each of the aspects. In the twentieth century, 'Counter-Enlightenment' and Gegenaufklärung in the respective English and German-speaking contexts appear as primarily polemical concepts in the debates on the definition of modernity. While it is certainly true that philosophy in the nineteenth century, beginning with the early romantics on either side of the Rhine through Hegel and on to Nietzsche, was continuously struggling with the Enlightenment, it no longer did so in a purely antagonistic manner. And with regard to the eighteenth century, the concept of Counter-Enlightenment can ultimately only be understood as a descriptive heuristic concept rather than as a category used by the protagonists themselves.

Although the concept does not allow for any substantial definition, it does good service in the provisional identification of positions against the dominant Enlightenment that have hitherto remained unexplored and which may lead to additional findings in view of a broader and more differentiated approach to the epoch, reconsidering its actors, media and cultural practices. As a collective category, however, it does obscure more than it illuminates and blocks from view the multitude of political options that developed at the turn of the century. The fact that the protagonists involved showed a similar attitude towards eighteenth-century philosophy does not turn them into representatives of one single or even homogeneous ideology. In this perspective, separating a negative Counter-Enlightenment characterised as pure antagonism from early romantic tendencies which lead in a constructive-critical way to early conservatism as do Christoph Weiß and Wolfgang Albrecht, does not seem to be helpful either. ${ }^{40}$ Rather than orderly separated ideological positions, the turn of the century showed a tremendous strife for political differentiation. As the French political scientist Olivier Nay states: 'Qu'y a-t-il de commun entre la pensée réactionnaire, le libéralisme orléaniste, le traditionalisme religieux, le nationalisme romantique ...?'41 


\section{Beyond Enlightenment and Counter-Enlightenment: A Sociological Synthesis}

When at the beginning of the twentieth century historical scholarship addressed the genealogy of the different conservative and reactionary political strands, the notion of Gegenaufklärung played an important role. In this context, the term was used for the very first time in the current sense of a counter movement against the Enlightenment. In German, the term Gegenaufklärung had been unknown in the eighteenth century, though not the phenomenon of contrary reaction to the ideas of the Enlightenment. It is mentioned once in an anonymous contribution to the Deutsche Monatsschrift of I790, published by Friedrich von Gentz and Gottlob Nathan Fischer. This polemic asks: 'What can the antidote to the Enlightenment be ... except the Counter-Enlightenment to Mirabeau's Enlightenment?' 42

The term did not reappear in a similar sense until I9I2, in a contribution which, more than a century post factum, bemoans the inability of the Catholic Church to put a stop to the Enlightenment movement. To explain this failure, an article in the journal Historisch-politische Blätter für das katholische Deutschland argues that "Apart from the lack of solidarity ... the clergy lacked two things, namely scientific and popular Counter-Enlightenment' ${ }^{43}$ Less than outright opposition, the meaning of the phrase here is closer to the English idiom 'counterintelligence'.

As far as I can see, the first systematic use of Gegenaufklärung in the sense discussed here can be retraced to the period between the two World Wars, which was marked by the search for a new self-understanding following experiences of disintegration that arose during World War I. The concept of Counter-Enlightenment is used in the first volume of Franz Oppenheimer's sociological classic System of Sociology from I922, denoting a systematic categorization of post-revolutionary opposition against the Enlightenment. Oppenheimer basically assumes that the object of sociology is the question of 'consensus,' the condition under which life in society is possible. Historically he regards sociology as a daughter of the French Revolution, which serves as the guiding force of social and political reform. This relation to the French Revolution also determines the relationship between sociology and the Enlightenment. Oppenheimer understood the Enlightenment entirely in the sense of nineteenth-century historiography, as the cause and "principle of the 
Revolution' 44 by whose failure the Enlightenment itself was discredited. According to Oppenheimer, "it is impossible to exaggerate the impression which the fiasco of the revolution exerted on contemporaries, and the change in the thinking of the class of citizens it produced'. ${ }^{45}$

Thus, there were groups that were 'deeply repulsed by the horrors of the Reign of Terror' ${ }^{46}$ and turned against the Enlightenment, which so far had consisted of the beneficiaries of the absolutist rule. According to Oppenheimer, these include

French traditionalists such as Maistre and Bonald and German 'reactionaries' like Haller; the 'social conservatives', as in France Simonde de Sismondi and in Germany Möser, German feudal aristocrats like Fouqué and Arnim, bourgeois swarmers of the guilded period, such as Tieck and Wackenroder, 'historical liberals' such as Görres in his first period and later Friedrich List, and genuine Romantics as in France with Châteaubriand [sic] and in Germany with Friedrich Schlegel and above all Adam Müller. ${ }^{47}$

Oppenheimer rejects the label 'romantic' for those he mentions and instead proposes the notion of an 'intellectual Counter-Revolution' ${ }^{48}$ No matter how different the thinking of the protagonists may be, according to Oppenheimer they are united by their opposition to the Enlightenment and the Revolution that emerged from it. He mentions Edmund Burke, who was promoted by Maistre and Bonald in France and by his translator Friedrich von Gentz as well as by Adam Müller in Germany. Oppenheimer outlines the 'idea of intellectual CounterRevolution' as 'the photographic negative of Enlightenment':

Enlightenment is individualistic, rationalistic, and unhistorical, indeed anti-historical. Thus, the counter-movement is 'universalistic' or 'organic', i.e. it proceeds from the totality rather than from the absolutized individual; it is also 'irrationalistic', that is, it does not believe in the subjective individual intellect, but in the collective reason which unfolds in language, law, and state, and is thereby justified, and thereby based, historically, on what has already become legitimate. Even in Herder peoples no longer appear merely as more or less adult specimens of one and the same species, but as individualities sui generis. ${ }^{49}$ 
Oppenheimer constructs the contrast between the two movements, i.e. Enlightenment and Counter-Revolution, as thesis and antithesis. In this way he can construe the sociology of Henri de Saint-Simon and Auguste Comte as a synthesis of the two: 'With this, we have gained thesis and antithesis: Enlightenment and Counter-Enlightenment in their decisive elements. Young sociology is an attempt at synthesis!' 50 Sociology, according to Oppenheimer, takes up basic elements of both movements. While the Enlightenment proceeds from 'abstractly conceived individuals who are imagined to be free from every concrete social bond', sociology adds the element of the non-additive collective. Its object is the 'whole of concrete, historically given society as an organic unity'.$^{51}$

Here, Oppenheimer takes up a classic critique of the Enlightenment, its alleged individualism. This aspect of the formation of counterrevolutionary theory, the discovery of society as a totality that is not made up of individuals but precedes the individual with its order and the forms, habits and customs inscribed in it, receives sustained attention throughout the nineteenth and twentieth centuries. In Germany, the philosopher Robert Spaemann in I959 gave his book on Bonald a title that eventually became a slogan: The Origin of Sociology in the Spirit of Restoration. For Bonald, as Spaemann writes, social unity is still deemed metaphysical, but nevertheless develops in a functionalist manner. Only Auguste Comte, according to Spaemann, would eliminate the metaphysical nucleus and pursue sociology as a positive science that describes the laws of society without reference to transcendent causes..$^{52}$ As a matter of fact, the disintegration of society in the modern world would later be criticized in the name of an overtly counter-enlightened idea of social unity, especially by German sociologists from the I950s onward, which I will discuss below.

It is Karl Mannheim, the successor to Oppenheimer's chair of sociology in Frankfurt, who takes up the distinction between Enlightenment and Romanticism as its counter-movement, but without sharing Oppenheimer's idea of a synthesis in sociology. Rather, in his view their opposition is a structural prerequisite for the emergence of conservatism in the modern sense. 'It is well known,' says Mannheim, explicitly referring to Oppenheimer, 'that romanticism developed from Enlightenment as antithesis to thesis. Since every antithesis is conditioned by the thesis it opposes, romanticism, as a counter-movement, 
suffered the paradoxical fate that its structure was fundamentally conditioned by the attitudes and methods of the very Enlightenment which had provoked it. ${ }^{53}$ For Romanticism preserves what would be lost in the rationalist Enlightenment:

The sociological significance of romanticism lies in its achievement, as experiential reaction against Enlightenment thinking (the philosophical proponent of bourgeois capitalism), in seizing on earlier, declining forms and contents of life, elaborating them at a conscious level, and setting them up against the rationalist style of thought. Romanticism took up just those attitudes and spheres of life that were surviving as mere undercurrents which bourgeois rationalism threatened to override. ${ }^{54}$

In other words, to define romanticism in purely negative, antagonistic terms neglects its function as a preserver of tradition:

There would be nothing wrong with this if romanticism had not had positive contents of its own rather than being mere negation, namely those preserved from past ages ... We must therefore distinguish between two factors in romanticism: firstly, a factor which gives romanticism the appearance of a spiritual counter-movement to the Enlightenment (it is determined in regard to all these points by the adversary against whom it struggles), and secondly, its function as heir of a style of thought and life which capitalism had pushed aside. .5

In Germany, the historiography of conservatism came into being with Karl Mannheim, who opened up a whole new field of research for generations of upcoming researchers. For Mannheim, conservatism appears as the phenomenon of a modern, dynamically transformed world, ${ }^{56}$ which signals a break with the static concepts of traditionalism and Counter-Enlightenment. In Mannheim's view, traditionalism signifies a pure adherence to the past while Counter-Enlightenment amounts to nothing more than bipolarity towards the Enlightenment. In this respect, I fully agree with the historian Reinhard Laube who, in a very discerning and trenchant analysis of Mannheim's relationship to his own present around the time he wrote the book in the I920s, once called the theory of conservatism a 'contribution to the self-description of modern society', referring to 'the significance of themes of conservatism 
and romanticism in the intellectual discourses of the interwar period'. According to Laube, Mannheim's sociology of knowledge provides 'a highly politicized interpretative scheme in the guise of a profile of an epoch's reception, which served as a key for deciphering bourgeois society and its representatives'. ${ }^{57}$ For Laube the French Revolution is less an historical watershed than a symbol of the era of 'political and industrial double revolution'. ${ }^{8}$ In this way, Laube adds, 'the conservative insistence on concreteness, substance and qualities becomes transparent as a strategy to deal with the abstract, functional and quantifying tendencies of modernity, which are also conceived as the result of a bourgeois rationalistic Enlightenment' ${ }^{59}$ We have in one: the beginning of the historiography of conservatism as well as an example for how in a time of crisis like the I920s the debate about Enlightenment and its opponents serves as a mode of self-reflection of the time - which it is up to today.

\section{The Contested Legacy of the Enlightenment in the Twentieth Century}

In most of the more recent literature on Counter-Enlightenment, it goes unquestioned that the term was coined by Isaiah Berlin in a contribution to the Dictionary of the History of Ideas of I973. Isaiah Berlin himself did not help to clarify the facts when he replied to a question about the origin of the concept in a conversation with Ramin Jahanbegloo: 'I don't know who invented the concept ... Someone must have said it. Could it be myself? I should be somewhat surprised. Perhaps I did. I really have no idea. ${ }^{\prime}{ }^{60}$ Indeed, as mentioned earlier, the terms Gegenaufklärung, 'Counter-Enlightenment' and Anti-Lumières did not become common for describing the various phenomena mentioned until the second half of the twentieth century. Good empirical points of departure for the history of the concept are the studies by the Boston political philosopher James Schmidt. By using internet-based surveys, Schmidt has built a solid factual foundation. ${ }^{61}$ And it is also Schmidt who has put forward convincingly that reference works like the Dictionary of the History of Ideas are hardly the place where new concepts are created. Rather, a term will only be codified on the condition that it has already found its way into the lexicon. 
This was indeed the case around the time Berlin wrote the article in the early I970s. In the second half of the twentieth century, the concept had been used by Anglophone writers in significant although limited ways in literary studies, history, social sciences and also in the broader intellectual debates of the time. ${ }^{62}$ Especially one source to which Berlin possibly had access and to which Henry Hardy, Berlin's literary executor, calls attention, might have been decisive. ${ }^{63}$ In his history of Early German Philosophy, Lewis White Beck, an American specialist of German philosophy, dedicates a whole chapter to the 'CounterEnlightenment' which he identifies as 'philosophical criticism of the dominant intellectual positions' of the eighteenth century. He does so by citing Hegel's Phenomenology of the Spirit and supposing an intellectual and historical movement of thesis and antithesis similar to others before in Germany as that of Reformation and Counter-Reformation. "At the height of the German Enlightenment there was a reaction which I shall call the "Counter-Enlightenment", he concludes. ${ }^{64}$ In the following paragraphs, Beck enumerates some of the same authors also Berlin should list in his later article, as for example Johann Georg Hamann and Johann Gottfried Herder. Whereas Beck's interest is mainly in early historicist and pre-romantic thought in the history of German philosophy, Isaiah Berlin places it in the perspective of later 'romantic, vitalistic, intuitionist, and irrationalist writers, both conservative and socialist' ${ }^{65}$ which ultimately in his view 'inspired nationalism, imperialism, and finally, in their most violent pathological form, fascist and totalitarian doctrines in the twentieth century' ${ }^{66}$ Thus, Berlin brings the discussion about the fate of liberal democracies to a conclusion that began after World War II and determined the debates of the I950s and I960s in Europe as well as in the United States.

William Barrett, an expert in nineteenth and twentieth century continental philosophy and at the time editor of the Partisan Review, famously employed the term 'Counter-Enlightenment' in a debate with Lionel Trilling which was published in a series of articles in I949. The debate took its starting point from the question if liberalism was able to produce literature 'which can strongly engage our emotions' ${ }^{67}$ Whereas Trilling sees Enlightenment and Romanticism, reason and belief in a dialectical relationship, Barrett conceives the opposition as one between Enlightenment and Counter-Enlightenment, a 'deepseated conflict between instinct and reason that has become articulate in 
Western culture during the last I 50 years' and in which 'it is only reason at last that can adjudicate'. ${ }^{68}$ While he agrees with Trilling that Western culture is shaped by the antagonism between those two tendencies, he decides in favour of the Enlightenment: 'it is to the Enlightenment we must, in the end, give primacy. ${ }^{69}$ From a terminological angle, Trilling's and Barrett's approaches serve as prime examples; both identify an antagonistic relationship, but by opposing the asymmetrical expressions 'Enlightenment' and 'Counter-Enlightenment' Barrett signals a value judgement. At this point we are already able to identify the two elements Isaiah Berlin would draw upon twenty years later: the debate about contemporary liberalism and romantic philosophy.

We can retrace a similar development in Germany, where Gegenaufklärung became a polemic slogan in the politically charged public debates following the student protests. But the term has already been in use since the immediate post-war period, when it was mainly employed in sociology and with respect to the self-understanding of modern societies. In both the U.S. American and German contexts, it is quite obvious that the term 'Counter Enlightenment' was used as a polemical rejection by those who unambiguously advocated in favour of Enlightenment and social progress.

Probably the most prominent example, written and published almost simultaneously to Berlin's encyclopaedia entry, is Hermann Lübbe's I972 volume on University Reform and the Counter-Enlightenment named after the eponymous and polemic article 'Gegenaufklärung' that had first been published in August I97 I by Deutsche Zeitung - Christ und Welt, a conservative newspaper that was closely affiliated with the protestant church..$^{70}$ The political philosopher Lübbe used the concept of Gegenaufklärung in an inverted and instructive manner, which implied that some knowledge of historical agents and patterns of action must have been widespread, at least in some stereotyped form. Otherwise the rhetorical figure would have made little sense. Lübbe writes: 'The culture of a new Counter-Enlightenment is unmistakably spreading ... So-called critical intelligence, primarily academic, is the carrier of the new movement of Counter-Enlightenment, and in universities centres of political salvation are being founded on the basis of moralityconfounding arrogance, intrusive moralism and fervent intolerance.' ${ }^{71}$

Lübbe compiled a number of phenomena as Counter-Enlightenment features that he believed he was observing at German universities. 
These included escapism into ideological orthodoxy, the treatment of texts such as Marx's Das Kapital as 'sacred', iconolatry and a ritualistic worship of inscriptions both of which materialized as murals of ideological leaders (Mao and Lenin, Che Guevara and Fidel Castro), and even restricted freedom of information. ${ }^{72}$ Paradoxically, it seemed to Lübbe that precisely those groups that understood themselves as most enlightened and critical showed modes of behaviour and forms of thought which could be portrayed most appropriately with motifs drawn from the darkest features of the early nineteenth century.

Lübbe's rhetorical strategy of characterizing particularly those groups as being part of a Counter-Enlightenment who perceived themselves as representatives of a political and intellectual avantgarde, was only possible against the background of two preconditions. First, these groups had to claim explicitly to be representatives of the Enlightenment; second, the concept of Counter-Enlightenment had to be so widespread that its mere mention could call forth frightening associations of oppression, censorship, and spiritual decline. In fact, the highly politicized period of the I 960 os has been characterized by intense clashes over the ambivalent consequences as well as the positive legacy of the Enlightenment. ${ }^{73}$ This discussion was not new, but in post-war Germany it was conducted with a view to the most recent past, that is, the political, social and cultural failure to resist National Socialism and fascism, and at the same time with an awareness of the continuation of totalitarianism in the Communist East. Intense reflection upon the importance and legacy of the Enlightenment neither took place in the contexts of historiography nor political science; instead, the according debates were conducted in sociology.

These efforts followed the culturally pessimistic diagnoses that were so characteristic for the attempt to determine the understanding of the post-war present in relation to the Enlightenment. The use of the term 'Counter-Enlightenment' reflected this ambivalent reference to the Enlightenment. An example is the work of Arnold Gehlen, beginning with his main study Man, his Nature and his Position in the World from I940, which was reissued in I950 in a profoundly altered edition, as well as the further works of the I950s such as Primitive Man and Early Culture from 1956, or The Soul in the Technological Age from 1957. Through reactions to Gehlen's philosophical doctrine of institutions, a separate discussion developed about whether his 
critical attitude towards the Enlightenment was based on mistrust in the Enlightenment, whether his own time, as Gehlen himself states, was 'after-Enlightenment' (Nach-Aufklärung), or whether Gehlen's position should not rather be interpreted as a 'productively contrasting' Counter-Enlightenment. ${ }^{74}$ Still in I989, the Frankfurt political scientist Iring Fetscher described Gehlen's attitude as 'the only ambitious antiEnlightenment position in the Federal Republic', although his arguments in Fetscher's view 'at the same time owed their possibility to a far advanced Enlightenment' ${ }^{75}$

In a similar manner, Gehlen's former student and assistant Helmut Schelsky uses the concept of Counter-Enlightenment as a reflection of the Enlightenment. In his Sociology of Sexuality, he deals with the double meaning of the word Aufklärung. The book is an ongoing examination of the I 948 and I 953 studies by the American sexologist Alfred Charles Kinsey, the so-called Kinsey reports, which led to a lively debate in the United States upon their immediate release. ${ }^{76}$ The accusation was that Kinsey's description of diverse behavioural patterns, including those that deviated from social norms, elevated biological facts to moral 'naturalness' and thus made biology a normative science. Schelsky suggests that both sex education (in German also Aufklärung) and the historical Enlightenment movement for emancipation with its claim to open, rational investigation and criticism of all forms of life, called into question long-standing behaviours and thus 'only created new emergencies, insecurities, and diseases of human and social behaviour that were far more difficult to grasp and cope with than those the narrowness and limitations of tradition had caused'. ${ }^{77}$ In view of this situation, he argues that many scientific areas are concerned with 'recovering the functional significance of tradition through insight'. ${ }^{78}$ Schelsky describes this process as 'Counter-Enlightenment against the lack of depth of consciousness of the Enlightenment period and its movements', 79 a CounterEnlightenment that takes place in the service of tradition and the stabilization of society:

In the field of sexual behaviour - just as well as in many other areas of our social life - we are faced with a much more difficult task than to advance beyond obsolete traditions or, conversely, to preserve them. We are faced with the task of establishing new traditions. This cannot be accomplished 
by means of science; but science can help to create a general consciousness that does not hinder this creative achievement of social stability by means of a pseudo-scientific solution. ${ }^{80}$

Indeed, Schelsky explicitly adopts the notion of Counter-Enlightenment by positively reinterpreting an obscurantist critique of his sociology of sexuality: 'Scientific progress lies in the constant increase of rationality; the naiveté and the affectation of thought in the selfconsciousness of "progress" and the "Enlightenment" is precisely one of the illusions against which I have directed my formula of "Counter-Enlightenment", ${ }^{81}$

Finally, the title of Niklas Luhmann's inaugural lecture, which he published in I967 under the title 'Sociological Enlightenment' in Soziale Welt, one of the most important German sociology journals, has become almost proverbial. At the beginning of his text, Luhmann traces back the relationship of well-known German sociologists, by then considered classics, to the Enlightenment: Karl Mannheim, Ralf Dahrendorf, Arnold Gehlen and Helmut Schelsky. He concludes that twentieth-century sociology dissociates itself from the Enlightenment and ties this outcome to an epochal disruption, a break between Enlightenment thought and sociology. Luhmann does not end his conclusion with a mere antagonism, though. Sociology as a form of Enlightenment remains possible as long as it serves the task of 'clarifying the Enlightenment' ('Abklärung der Aufklärung') by determining the boundaries of Enlightenment thought. ${ }^{82}$ His aim is to establish a new, positive relationship between sociology and the Enlightenment, thus going beyond the Counter-Enlightenment genealogy of sociology.

It has become clear that 'Counter-Enlightenment' is far more than a derogatory term used to dismiss a political opponent. As a slogan, it foregrounds the task of measuring the capacities and the limits of social progress in the post-war context. At the time it was phrased as an ideological term during the I950s, the concept was deeply informed by modernity theory. This obviously corresponded to a social and political situation common to Western societies, in which the progressive and optimistic understanding of modernity was being called into question. The representatives of, as they called themselves, the sociological Counter-Enlightenment set the stabilizing function of 
institutions and the separation of a space of moral norms from the area of scientific knowledge against the notion of a comprehensive emancipation of society. This may be what the sociologist Friedrich Jonas, a former assistant to Arnold Gehlen as well as to Helmut Schelsky, suggested about Bonald, Maistre and their German successors, namely: that the principle of the Counter-Enlightenment can be seen as an attempt to bring an emancipated society back under a politically controlled order. ${ }^{83}$

\section{Conclusion}

The designation 'Counter-Enlightenment' can be a powerful verdict in political debates marked by deeply antagonistic positions. As the German historian Reinhart Koselleck once stated, rigorous dualisms have always been particularly efficacious in political conflicts. But at the same time, one is well-advised to also follow Koselleck's recommendation as to the use of such dualisms in historical research which says that 'past antitheses have tended to be too crude to serve as categories of historical knowledge' ${ }^{8}{ }^{84}$ Newer research on Counter-Enlightenment as undertaken by Masson and McMahon has followed this path. They take the opposition between the participating actors, one might call it the Enlightenment Counter-Enlightenment divide, as a point of departure, but reconfigure the cultural space along different lines, be it the dialectical constitution of modernity (McMahon) or the socio-political and cultural reconstitution of intellectual milieus (Masson). At the same time, they make more clearly perceptible the powerful effects of group-formation by polemical adversity. It has been shown in numerous studies in what ways the acting groups of the eighteenth century were less formed by self-organization or ideological commonalities but rather by ascription. This is especially true for the 'philosophers' who became the dangerous 'league' mainly by those who opposed them ${ }^{85}$ - who, in turn, were no unified and closed group either but came from a number of different backgrounds. ${ }^{86}$

In these studies as well as in others, the opposing concepts have proved to be a productive point of departure: not more, but not less than that either, and to my opinion, there is no need to ban the notion of Counter-Enlightenment from the historians' vocabulary altogether. As my overview has shown, whereas the conflicts it denotes were 
contemporary to the eighteenth century, the word itself is not. At the time, far more colourful expressions were deployed in the rather nonacademic struggles, ${ }^{87}$ such as dévots, obscurants, zealots, zion's wardens (Zionswächter), fanatics and so forth. ${ }^{88}$

When 'Counter-Enlightenment' (and its French and German equivalents) finally came into use, it was not as a polemical term, but as an analytical one that aimed to describe the opposition between Enlightenment and its counter reactions in the wake of the French Revolution. This distinguishes the two corresponding terms 'Enlightenment' and 'CounterEnlightenment' from the antagonistic couple revolution/reaction Jean Starobinski conducted an instructive study about. As Starobinski shows, the pairing was not created in hindsight, but simultaneously with the polarization of the political space, reflecting the idea of progress in political institutions. What the two have in common, on the other hand, is the fact that they can be and actually were again used to polarize intellectual and political debates. ${ }^{89}$

As high as this polarizing potential may be and as immediately perceptible it has become again in present debates, the history of the word points to a quality that goes beyond the mere formation of oppositions. From the onset, the attitude towards the Enlightenment was one to the respective present. If it is true that 'the Enlightenment was the founding of modernity', ${ }^{\circ}$ then also the fight against it is part and parcel of modernity - if we do not try to exclude the anti-modern from it but see the antagonism of the two as irreducible. ${ }^{91}$ In this respect, CounterEnlightenment has not been used as a marker of opposition, but as a term of self-reflection of the modern condition. As argued in the above paragraph on German post-war sociology, the term entails a fundamental mistrust against an illusionary technical and scientific progress, the loss of tradition and cultural identity. It conveys a more pessimistic attitude against modernity compared to the optimistic progressivism prevalent at the time. It is exactly in this respect that I deem it important to continue or even intensify our engagement with the concept of Counter-Enlightenment: it will allow us to learn more about the world we live in. This may not to make us more enlightened, but certainly more clarified (which would be abgeklärt in German), as was said about Friedrich Jonas in a I 968 obituary. There, he was characterized as 'a Counter-Enlightener' who 'expressly accepted this designation ... But he was no opponent of the Enlightenment insofar as it wanted to 
shed light on the necessities of our thinking and acting. He just did not share the hope of the Enlightenment that we would be happier as a result. ${ }^{\prime 2}$

\section{Notes}

I Ariane Chemin and Vincent Martigny, 'Qui veut éteindre les Lumières?', Le Monde (I7 November 2018).

2 Joseph Mali, 'The Invention of the Counter-Enlightenment: The Case for the Defense', in Asaph Ben-Tov, Yaacov Deutsch and Tamar Herzig (eds), Knowledge and Religion in Early Modern Europe: Studies in Honor of Michael Heyd (Leiden, 20I3) 205-28. See also the six contributions about 'Fabricating the Counter-Enlightenment' on James Schmidt's blog 'Persistent Enlightenment', https://persistentenlightenment. com/20I3/Io/I 4/counter-enlightenmentI/ (accessed 29 August 20I9).

3 Cf. Jeremy L. Caradonna, 'There was no Counter-Enlightenment', Eighteenth-Century Studies 49 (2015) 5I-69, at 52: 'the CounterEnlightenment is a political trick - even a bit of unintended Cold War propaganda'. Likewise, James Schmidt, 'The Counter-Enlightenment: Historical Notes on a Concept Historians Should Avoid', EighteenthCentury Studies 49 (2015) 83-6.

4 Several authors proceed from an abstract concept of a trans-historical Counter-Enlightenment. Cf. Jochen Schmidt (ed.), Aufklärung und Gegenaufklärung in der europäischen Literatur, Philosophie und Politik von der Antike bis zur Gegenwart (Darmstadt, I989); Mark Lilla, 'What is Counter-Enlightenment?', in Joseph Mali and Robert Wokler (eds), Isaiah Berlin's Counter-Enlightenment (Philadelphia, 2003) I-II; Graeme Garrard, Counter-Enlightenments: From the Eighteenth Century to the Present (London/New York, 2006). See also the discussion about the question of whether Herder can be categorized as a thinker of the CounterEnlightenment as Isaiah Berlin defined it: Robert E. Norton, 'The Myth of the Counter-Enlightenment', Journal of the History of Ideas 68 (2007) 635-58; Steven O. Lestition, 'Countering, Transposing, or Negating the Enlightenment? A Response to Robert Norton', Journal of the History of Ideas 68 (2007) 659-8I; Norton, 'Isaiah Berlin's "Expressionism”, or: "Ha! Du bist das Blökende!"', Journal of the History of Ideas 69 (2008) 339-47. A special case in these debates is that of Rousseau which requires a separate 
discussion. Within the given context, however, I consider it to be important to distinguish the internal struggles that arose from within the Enlightenment movement from the explicit attacks that originated outside the Enlightenment movement as opposed to authors who argue that Rousseau belonged to the Counter-Enlightenment or could even be considered as its founder. Cf. Garrard, Rousseau's Counter-Enlightenment: A Republican Critique of the Philosophes (New York, 2003); Carolina Armenteros and Richard A. Lebrun (eds), 'Introduction', in Joseph de Maistre and his European Readers: From Friedrich von Gentz to Isaiah Berlin (Leiden, Boston, 20 I I) 7.

5 Darrin M. McMahon, 'What is Counter-Enlightenment?', International Journal for History, Culture and Modernity, 5:I (2017) 33-46, https:// www.history-culture-modernity.org/article/Io.I8352/hcm.508/ (accessed 29 August 2019).

6 Didier Masseau (ed.), Dictionnaire des anti-Lumières et des antiphilosophes (France, I715-I815) (Paris, 2017).

7 James Schmidt, 'Inventing the Enlightenment: Anti-Jacobins, British Hegelians, and the "Oxford English Dictionary", Journal of the History of Ideas 64 (2003) 421-43. On the history of the concepts of Enlightenment and Aufklärung, see Robert Wokler, 'Isaiah Berlin's Enlightenment and Counter-Enlightenment', in Isaiah Berlin's Counter-Enlightenment, 13-32, 25-6, notes 3 and 4; McMahon, 'The Religious Enlightenment: A Useful Category of Research?', The European Journal 14 (2013) 1-4; John Lough, 'Reflections on Enlightenment and Lumières', Journal for Eighteenth-Century Studies, 8 (1985) 1-15.

8 Dan Edelstein, The Enlightenment: A Genealogy (Chicago, 20 I0) I I6.

9 Zeev Sternhell, Les anti-Lumières: Du XVIIIe siècle à la guerre froide (Paris, 2006), Chapter VII.

Io Isaiah Berlin, 'The Counter-Enlightenment', in Philip P. Wiener (ed.), Dictionary of the History of Ideas, vol. 2 (New York, I973) IOO-I2. Ironically enough, Sternhell classifies Berlin as a Counter-Enlightenment thinker for his liberal convictions. Cf. Sternhell, Les anti-Lumières, 495-6.

I I A research which differs significantly from the often very uninformed use of the concept not only in public discourse, but also in areas outside the core of eighteenth-century studies. I fully agree with the historian Theo Jung who opposes the 'fine-grained analytical concepts of CounterEnlightenment found in recent research' to 'their relatively one-dimensional counterparts in other areas of public discourse', but would not follow his conclusion that the concept is of too little analytical value to continue using 
it. Cf. Theo Jung: 'Multiple Counter-Enlightenments: The Genealogy of a Polemics from the Eighteenth Century to the Present', in Martin L. Davies (ed.), Thinking about the Enlightenment: Modernity and its Ramifications (London, New York, 2006) 209-26.

I2 Jean Deprun: 'Les Anti-Lumières', in Yvon Belaval (ed.), Histoire de la Philosophie II: De la Renaissance à la Révolution Kantienne (Encyclopédie de la Pléiade, vol. 36) (Paris, I973) 717-27, at 717.

I3 Ibid., 726.

I4 The expression is used by Deprun. Cf. ibid., 7I 7 .

I5 Masseau, Les ennemis des philosophes: L'antiphilosophie au temps des Lumières (Paris, 2000); McMahon, Enemies of the Enlightenment: The French Counter-Enlightenment and the Making of Modernity (Oxford, 200I).

I6 Cf. McMahon, 'The real Counter-Enlightenment: The Case of France', in Mali and Wokler (eds), Isaiah Berlin's Counter-Enlightenment, 9I-I04, 93.

I7 Cf. Hans Ulrich Gumbrecht and Rolf Reichardt, 'Philosophe, philosophie', in Handbuch politisch-sozialer Grundbegriffe in Frankreich I680-I820, Heft 3 (Munich, I985) 7-88.

18 Albert Monod, De Pascal à Chateaubriand: Les défenseurs français du christianisme de I670 à I802 (Paris, I9I6); Robert R. Palmer, Catholics and Unbelievers in I8th Century France (Princeton, 1939). Contemporary approaches to the Enlightenment historiography go so far as to characterize the manner in which Catholic writers adopted new strategies of argumentation and representation in the emergent public media as an ecclesiastical reform movement under the banner of 'Catholic Enlightenment'. Cf. Ulrich L. Lehner and Michael Printy (eds), A Companion to the Catholic Enlightenment in Europe (Leiden, Boston, 20I0); Lehner and Jeffrey Burson (eds), Enlightenment and Catholicism in Europe: A Transnational History (Notre Dame, 2014); Lehner, The Catholic Enlightenment: The Forgotten History of a Global Movement (Oxford, 20i6); Helena Rosenblatt, 'The Christian Enlightenment', in S. J. Brown and T. Tackett (eds), The Cambridge History of Christianity: Enlightenment, Reawakening and Revolution, I660-I8I5 (Cambridge, 2006) 283-30I. In my view, these works underrate the controversialist character of literary production.

I9 Masseau, Dictionnaire des anti-Lumières, 9.

20 See, for example, the articles on different journals as well as on the 'Pamphlets antiphilosophiques'. Cf. ibid., 806-4I and I i65-8.

2I Cf. ibid., I6-I 7 for the periodization in the French context. 
22 Cf. Christoph Weiß and Wolfgang Albrecht (eds), 'Einleitende Bemerkungen', in Von 'Obscuranten' und 'Eudämonisten': Gegenaufklärerische, konservative und antirevolutionäre Publizisten im späten I8. Jahrhundert (St. Ingbert, I997) 7-34, I6-I7. Weiß's and Albrecht's collection still provides the most comprehensive overview for the German-speaking lands of the late eighteenth century.

23 It has to be taken into account that the term 'revolution' only acquired its full meaning after $\mathrm{I} 789$, i.e. once it lost its naturalistic meaning of 'a turning over' and became a collective singular with its specifically modern connotation. Cf. Reinhart Koselleck, 'Historical Criteria of the Modern Concept of Revolution', in Futures Past: On the Semantics of Historical Time (Cambridge, MA, London, 1985) 39-54.

24 Simon Burrows, French Exile Journalism and European Politics I792-I8I4 (Woodbridge, 2000) 9, I 5 .

25 Ibid., I43.

26 Ibid., I45.

27 Jacques Mallet du Pan, Mercure britannique ou notices historiques et critiques sur les affaires du tems (London, I798) 342-70.

28 Ibid., 345-6.

29 Ibid., 366-7.

$30 \mathrm{Cf}$. Wilhelm Kreutz, “'L'inscription qu'on pourra mettre sur les ruines des trônes ... peut être conçue dans ces deux mots: "L'ouvrage de l'Illuminatisme!": Johann August Starck und die "Verschwörungstheorie"”, in Weiß and Albrecht, Von 'Obscuranten' und 'Eudämonisten', 269-304, 279-80.

3I Cf. Ralf Klausnitzer, 'Unsichtbare Kirche, unsichtbare Hand: Zur Imaginationsgeschichte geheimer Gesellschaften in der Vorromantik und bei Ludwig Tieck', in Institut für deutsche Literatur der HumboldtUniversität zu Berlin (ed.), 'lasst uns, da es uns vergönnt ist, vernünftig seyn!': Ludwig Tieck (I773-I853) (Bern, 2004) 7I-I I2, at 83; Sylvia Schaeper-Wimmer, Augustin Barruel, S. J. (I74I-I820): Studien zu Biographie und Werk (Frankfurt am Main, 1985).

32 Johann August Starck, Der Triumph der Philosophie im Achtzehnten Jahrhunderte, 2 vols. (Germantown, I 803).

33 Ibid., vol. I, I.

34 J.G.A. Pocock: 'Enlightenment and Counter-Enlightenment, Revolution and Counter-Revolution', in History of Political Thought 20: I (I999) I25-39, at I30. 
35 See also Günther Lottes, 'Das revolutionäre Frankreich als Trauma der deutschen Konservativen:Zur Verschränkung von Wahrnehmungsprozessen und politiktheoretischen Diskursen in der ersten Hälfte des I9. Jahrhunderts', in Hans-Jürgen Lüsebrink and János Riesz (eds), Feindbild und Faszination: Vermittlerfiguren und Wahrnehmungsprozesse in den deutsch-französischen Kulturbeziehungen (1789-1983) (Frankfurt am Main, I984) I3-24, at I5-I6.

36 Richard Mahrenholtz, Voltaires Leben und Werke (Oppeln, I885) I77.

37 August Wilhelm Rehberg, Untersuchungen über die Französische Revolution: nebst kritischen Nachrichten von den merkwürdigsten Schriften welche darüber in Frankreich erschienen sind, 2 vols. (Hannover/ Osnabrück, I793). About the relation to natural law, see Karl Mannheim, Conservatism: A Contribution to the Sociology of Knowledge (Collected Works, vol. II), ed. by David Kettler, Volker Meja and Niko Stehr, translated by David Kettler and Volker Meja (London, I986) I3I; Klaus Epstein, The Genesis of German Conservatism (Princeton, I966) 547-8.

38 Jonathan Allen Green summarizes Gentz's approach as follows: 'In fact, Gentz used his translation to defend a form of anti-revolutionary rationalism that was a self-conscious alternative to Burkean traditionalism.' Jonathan Allen Green, 'Friedrich Gentz' translation of Burke's Reflections', The Historical Journal 57, 3 (2014) 639-59, at 645.

39 Cf. Iwan Michelangelo d'Aprile, Die Erfindung der Zeitgeschichte: Geschichtsschreibung und Journalismus zwischen Aufklärung und Vormärz (Berlin, 2013) I22-3.

40 Weiß and Albrecht, Von 'Obscuranten' und 'Eudämonisten', Io.

4I Olivier Nay, Histoire des idées politiques (Paris, 2004) 329.

42 Anon., 'Kritischer Versuch über das Wort Aufklärung', Deutsche Monatsschrift III (I790) 205-37, at 233: 'Was kann das Gegengift der Aufklärung ... anders seyn als eine Gegenaufklärung gegen Mirabeau's Aufklärung.' For a contextualisation of this passage, see James Schmidt, 'Light, Truth, and the Counter-Enlightenment's Enlightenment', in Anton M. Matytsin and Dan Edelstein (eds), Let there be Enlightenment: The Religious and Mystical Sources of Rationality (Baltimore, 2018) 268-90, at 284 .

43 Anton Döberl, 'Abt Rupert Kornmann von Pristing: Ein Beitrag zur Geschichte der Aufklärung, Säkularisation und Restauration im Bistum Regensburg', in Historisch-politische Blätter für das katholische Deutschland I 49 (I9I2) 837-55, at 842 . 
44 Franz Oppenheimer, System der Soziologie, vol. I (Jena, I922) 3.

45 Ibid.

46 Ibid.

47 Ibid., 3-4.

48 Ibid., 4 .

49 Ibid., 6.

50 Ibid. The emphasis is mine.

5 I Ibid.

52 Robert Spaemann, Der Ursprung der Soziologie aus dem Geist der Restauration: Studien über L.G.A. de Bonald (Stuttgart, I998) I84.

53 Mannheim, Conservatism, 65.

54 Ibid.

55 Ibid., I95, note 37.

56 Ibid., 86.

57 Reinhard Laube, Karl Mannheim und die Krise des Historismus: Historismus als wissenssoziologischer Perspektivismus (Göttingen, 2004) 445 .

58 Ibid., 454.

59 Ibid., 455 .

60 Berlin and Ramin Jahanbegloo, Conversations with Isaiah Berlin (New York, I99I) 69-70. See also Berlins statements in a letter to Mark Lilla: James Schmidt, 'A Note on a Recently Published Letter from Isaiah Berlin on the "Counter-Enlightenment", https://persistentenlightenment. com/20I4/O2/I I/berlinletter/ (accessed 29 August 2019). John Pocock is equally convinced that Berlin did not invent the pattern of Enlightenment and Counter-Enlightenment since, as Pocock states, 'the entire literature of German historicism lies behind it'. Pocock 'Enlightenment and CounterEnlightenment', I30.

6I Cf. James Schmidt, 'Isaiah Berlin \& the "Counter-Enlightenment": A Reassessment (Fabricating the "Counter-Enlightenment" - Conclusion)', https://persistentenlightenment.com/20 I4/02/o5/c-e6/ (accessed 29 August 20I9).

62 Cf. James Schmidt, 'Charles W. Morris on Empiricism and the CounterEnlightenment (Fabricating the "Counter-Enlightenment" Part IV)', https://persistentenlightenment.com/20I4/oi/o7/countere4/ (accessed 29 August 2019).

63 Henry Hardy, 'Editor's Preface', in Isaiah Berlin, Against the Current: Essays in the History of Ideas (Princeton, 20I3), XXV, note I. Another 
important contribution to the question of Berlin's sources is Avi Lifschitz, 'Between Friedrich Meinecke and Ernst Cassirer. Isaiah Berlin's Bifurcated Enlightenment', in Laurence Brockliss and Ritchie Robertson (eds), Isaiah Berlin and the Enlightenment (Oxford, 2016) 5I-66, where Lifschitz argues for the significance of Meinecke's I936 work on the origins of German historicism for the formation of Berlin's portrayal of eighteenth-century Europe as sharply divided between two intellectual factions.

64 Lewis White Beck, Early German Philosophy: Kant and His Predecessors (Cambridge, MA, 1969) 362.

65 Berlin, 'The Counter-Enlightenment', Io6.

66 Ibid., I 12.

67 Lionel Trilling, 'A Rejoinder to Mr. Barrett', in Partisan Review 6:I6 (I949) $653-8$, at 655 .

68 William Barrett, 'Art, Aristocracy, and Reason', in ibid., 658-65, at 664.

69 Ibid., 665 .

70 At the time, even the widely read news magazine Der Spiegel released a review of Lübbe's anthology. Cf. Der Spiegel (13 March I972), I56-8.

7I Hermann Lübbe, Hochschulreform und Gegenaufklärung: Analysen, Postulate, Polemik zur aktuellen Hochschul- und Wissenschaftspolitik (Freiburg im Breisgau, 1972) 53.

72 Ibid., 54-5.

73 This debate continued until the I980s. Cf. Jens Hacke: Philosophie der Bürgerlichkeit: Die liberalkonservative Begründung der Bundesrepublik (Göttingen, 2008) I I3-4.

74 On the different positions in this debate see Karl-Otto Apel, 'Arnold Gehlens "Philosophie der Institutionen", Philosophische Rundschau Io (I962) I-2I; Klaus Dörner, 'Natur, Geschichte und Entfremdung bei Arnold Gehlen', Archiv für Rechts- und Sozialphilosophie 50 (1965) I0932; Friedrich Jonas, Die Institutionenlehre Arnold Gehlens (Tübingen, I966). In fact, Gehlen's understanding of the Enlightenment would be worth a deeper investigation. In the early editions of Man, he still employs the concept of Counter-Enlightenment whenever he considers the necessity of a 'Counter-Enlightenment in the spirit of science'. Cf. Arnold Gehlen, Der Mensch (Berlin, I94I) 347. In later editions, i.e. from I950 onwards, the term is removed.

75 Iring Fetscher, 'Aufklärung und Gegenaufklärung in der Bundesrepublik', in Jochen Schmidt (ed.), Aufklärung und Gegenaufklärung, 522-47, at 538. 
76 Amongst the various responses, the best-known is probably Lionel Trilling's critique, which was published in I952 under the title 'The Kinsey Report' in the first issue of the magazine Perspektiven. It was this version, translated into German, that was then quoted by Schelsky.

77 Helmut Schelsky, Soziologie der Sexualität (Hamburg, I955) 8.

78 Ibid.

79 Ibid.

80 Ibid., 9 .

8 I Helmut Schelsky, 'Verdunkelung oder Gegenaufklärung in der Soziologie der Sexualität: Zur Kontroverse Hochheimer-Schelsky', Psyche: Eine Zeitschrift für psychologische und medizinische Menschenkunde Io ( I956) $837-55$, at 855 .

82 Niklas Luhmann, 'Soziologische Aufklärung', Soziale Welt I8 (I967) 97-I 23.

83 Friedrich Jonas, Geschichte der Soziologie I: Aufklärung, Liberalismus, Idealismus (Reinbek bei Hamburg, I968) I63.

84 Reinhart Koselleck, 'The Historical-Political Semantics of Asymmetric Counterconcepts', in Futures Past, I59-97, at I62.

85 An analogous mechanism occurs in the semantic field of 'modernity'. Cf. Sonja Asal, "Was hieß "modern" im I8. Jahrhundert? Über ein begriffsgeschichtliches Missverständnis', in Olaf Asbach (ed.), Europa und die Moderne im langen I8. Jahrhundert (Hannover, 20I4) 63-83.

86 Cf. Masseau, Les ennemis des philosophes, 20.

87 Cf. Wolfgang Albrecht, 'In Biedermannsposen polemisch eifernd wider die "Epidemie der Aufklärungswuth": Ernst August Anton von Göchhausens Beiträge zur norddeutsch-protestantischen Gegenaufklärung', in Weiß and Albrecht, Von 'Obscuranten' und 'Eudämonisten', I55-92, at I60.

88 For the mutual attributions and the relations between the opponents, see Fritz Valjavec, Die Entstehung der politischen Strömungen in Deutschland: $I 770-I 8 I 5$, unaltered reprint of the first edition from I95I with a postface by Jörn Garber (Kronberg im Taunus, Düsseldorf, I978) 427-8.

89 Jean Starobinski, Action et Réaction: Vie et aventures d'un couple, revised edition (Paris, I999) 307-8.

90 Edelstein, The Enlightenment, I.

9I For a detailed discussion of this argument, see Antoine Compagnon, Les antimodernes: De Joseph de Maistre à Roland Barthes (Paris, 2005).

92 Horst Baier, 'Friedrich Jonas, Ein Nachruf', in Friedrich Jonas, Geschichte der Soziologie IV: Deutsche und amerikanische Soziologie (Reinbek bei Hamburg, I968) 270-I, at 27I. 


\section{About the Author}

After having obtained her $\mathrm{PhD}$ in Philosophy at Technische Universität Dresden, Germany, Sonja Asal has been working as editor of the Zeitschrift für Ideengeschichte and as a research manager in Munich and Berlin. Her academic work covers French and German intellectual history of the eighteenth and twentieth centuries with an emphasis on Counter-Enlightenment thought and theories of modernity. In Der politische Tod Gottes. Von Rousseaus Konzept der Zivilreligion zur Entstehung der politischen Theologie (2007), she analysed Rousseau's concept of 'civil religion' within the context of the relation between church and state in the ancien régime. Following her interest in the roles of media and institutions in intellectual history, Asal co-edited the publications Was war Bielefeld? Eine ideengeschichtliche Nachfrage (2009, together with Stephan Schlak) and Ernesto Grassi in München. Aspekte von Werk und Wirkung (2019, together with Annette Meyer). E-mail: sonja.asal@freenet.de 